\title{
КРЕМАТОРИУМ-ХРАМ, ИЛИ КРЕМАЦИЯ В СОВЕТСКОМ ПОХОРОННОМ ОБРЯДЕ 1920-Х ГОДОВ*
}

\begin{abstract}
В статье рассматривается история введения кремации в СССР в контексте процессов секуляризации похоронной культуры. В западноевропейском контексте, как и в дореволючиионном российском, легализация и распространение кремации существенно ограничивались огромным влиянием Церкви, которая традиционно выступала против этого нового вида погребения. В СССР после декрета «Об отделении ичеркви от государства и иколь от ичеркви» сложилась уникальная ситуащия, в которой все решения относительно утилизации мертвых тел принимались напрямую гражданскими властями, исходившими в первую очередь из соображений санитарии и гигиены больших городов. Однако и в этом случае, как оказалось, при выборе проекта и места строительства первого в СССР крематория (2. Петроград) фокусировались в основном на "[со]здании в массах необходимого духовного настроения», а сама постройка именовалась «Крематориум-Храм». Таким образом, несмотря на радикальную смену, по выражению английского исследователя Т. Уолтера, «режима распоряжения мертвыми телами» и переход монополии на погребение от Церкви к нарочито секулярному государству, идеологи кремации в СССР продолжали стремиться к созданию квазирелигиозного оформления новой погребальной практики. Однако ко второй половине 1920-х годов, когда строится Донской крематорий в Москве, отночение к кремаџии как к технологии оказывается значительно важнее.
\end{abstract}

Ключевые слова: кремация, CCCP, атеизм, body disposal practices, nохороны, гигиена, секуляризация

Промышленные революции, рост городов, размывание старых социальных иерархий привели к существенным изменениям в европейских обществах XIX в. Мощнейшие процессы трансформации культуры затрагивали самые разные аспекты - от архитектуры и планирования городов до семейных норм и морали. Однако, как бы быстро не менялось общество, старые институты продолжали накладывать серьезные ограничения на развитие давно назревших новых практик и форм. Одной из таких практик, появившихся на волне индустриального переворота, стала кремация, широко пропагандировавшаяся в Европе и Америке начиная со второй половины XIX в. как новый, прогрессивный, высокотехнологичный вид погребения, который

Соколова Анна Дмитриевна - к.и.н., н.с. Института этнологии и антропологии РАН (Москва, Ленинский пр. 32A). Эл. почта: annadsokolova@gmail.com. Sokolova, Anna D. -Institute of Ethnology and Anthropology RAS (Moscow, Leninsky pr. 32A). E-mail: annadsokolova@gmail.com

* Публикуется в соответствии с планом научно-исследовательских работ Института этнологии и антропологии РАН 
к тому же существенно выигрывает у традиционного трупоположения в санитарном и гигиеническом аспектах. Однако сторонники новой похоронной практики вскоре столкнулись с серьезным противостоянием Церкви, преодоление которого заняло у них несколько десятилетий.

Хотя кремационное движение в России появляется уже в конце ХІХ в., вплоть до 1917 г. оно остается достаточно маргинальным, в первую очередь из-за серьезного сопротивления со стороны Синода. Февральская, а затем Октябрьская революции 1917 г. создают новые возможности для развития общества, институциональных и вернакулярных практик, для реализации тех проектов, которые ранее вызывали сопротивление старых социальных институтов. Внезапно в зоне полной свободы оказалась и новая погребальная практика, получившая возможности для стремительного развития.

Однако в какой степени полная свобода и обновление, декларируемые революцией, действительно способны создать что-то принципиально новое, преодолеть преграды, которые, как казалось, ставила Церковь на пути новых похоронных практик, выйти за пределы архетипических рамок, которые сформировала культура в предыдущие столетия? В этой статье я покажу, что, несмотря на то что декрет Совета народных комиссаров РСФСР от 20 января 1918 г. «Об отделении церкви от государства и школы от церкви» полностью избавлял сторонников кремации от необходимости вписывать свою деятельность в рамки учения Церкви, они продолжали воспроизводить компромиссный в ее отношении дискурс или создавать квазирелигиозные конструкты вокруг новой похоронной практики вплоть до середины 1930-х годов.

Многообразие и историческая эволюция форм погребения неоднократно становились предметом анализа исследователей (Bremborg 2006; Laderman 2003; Sloane 1991; Goody, Poppi 1994; Suzuki 2000; Trompette 2011, 2013). По мнению Т. Уолтера - признанного классика death studies, такого рода многообразие определяется во многом базовыми принципами системы менеджмента погребения в разных странах. Иными словами, Уолтер утверждает, что архитектура управления погребением (или те, кто контролирует и утилизирует мертвые тела) является отличительной чертой, определяющей конкретную форму, которую принимает похоронная культура в той или иной стране (Walter 2005, 2012). В этой статье, следуя за идеей Т. Уолтера, я прослежу, как изменялась похоронная культура в раннем СССР в тот момент, когда монополия на погребение переходила от Церкви к новому светскому государству. Я покажу на примере введения практики кремации, как за десять лет между 1917 и 1927 годами происходит переход от квазирелигиозных форм к новым, связанным с идеей нового мира и нового человека.

\section{Кремационное движение Нового времени и Церковь}

Появление мощнейшего кремационного движения в XIX в. стало важной вехой в истории западноевропейской похоронной культуры. Однако легализация и развитие новой практики в большинстве стран находились в зависимости от позиции Церкви. Даже если ее иерархи и не высказывались напрямую ни о преимуществах какого-то вида погребения, ни о запрете кремации, трупоположение устойчиво воспринималось как основная погребальная практика в подавляющем большинстве христианских стран, а кремация, в свою очередь, как еретическая и даже богоборческая. Из-за серьезного сопротивления Церкви и общества распространение новой практики в 
Европе заняло десятилетия. Так, в Англии борьба за легализацию кремации длилась около 20 лет (Jupp 2006: 46-70), в некоторых землях Германии она не была официально признана вплоть до 1920-х годов (Блэк 2015: 61). Наибольшее противодействие распространению кремации оказала Римско-католическая церковь, наложившая запрет на кремацию в 1886 г. и сохранявшая его вплоть до II Ватиканского собора 1968 г. (Јирр 2006: 16).

Хотя ко второй половине XIX в. значительная часть европейского общества находилась под сильнейшим влиянием идей свободомыслия и эмансипации, ни о какой деклерикализации как государственной программе речь не шла. Вне зависимости от личных убеждений европейских активистов кремации они были вынуждены искать компромисс с Церковью и «договариваться» с ее иерархами. Отсюда появилось стремление разделить религиозную (проведение обряда) и санитарную (утилизация тела) потребности. Сведение кремации к чисто технической процедуре делало ее религиозную интерпретацию бесперспективной или как минимум менее конфликтной. Именно такая стратегия была выбрана первыми пропагандистами кремации в Англии (Јирр 2006: 7, 48-52, 57-58).

Этот подход не стоит рассматривать как некую уловку идеологов кремации, для того чтобы обойти негативное отношение христианских церквей. В частности, американский религиовед С. Протхеро отмечает:

Война между трупоположением и кремаций в Америке в свой ранний период велась, как правило, не между верующими христианами и скептиками-нехристианами. Напротив, это было в основном внутренним делом верующих христиан. Более того, нехристиане в рядах сторонников кремации очень редко были настроены секулярно. Они больше стремились к тому, чтобы ввести американские представления о смерти в новые духовные идиомы (Prothero 2001: 12).

П. Джапп, говоря о введении кремации в Англии, также подчеркивает отсутствие атеистического пафоса у сторонников этой похоронной практики (Jupp 2006: 55-57). Кремационное движение в Европе и Америке, таким образом, вынуждено было не противопоставлять себя учению Церкви, а вписываться в него и находить поддержку в недрах этого мощнейшего социального института.

\section{Легализация кремации в СССР}

История легализации и введения кремации в СССР существенно отличалась. До революции кремационное движение в России, также как и во всем мире, встречало существенное противодействие со стороны Церкви: Синод неоднократно блокировал попытки Министерства внутренних дел принять новый похоронный устав, предполагавший легализацию кремации (Белякова 2004: 537). Однако первые же законодательные инициативы молодой советской власти значительно меняют ситуацию: декреты СНК «Об отделении церкви от государства и школы от церкви» (20 января 1918 г.) и «О кладбищах и похоронах» (7 декабря 1918 г.) создают принципиально иные условия для отечественных сторонников кремации. Отделение от государства, в том числе и от похоронного дела, полностью снимало с повестки дня вопрос об отношении Церкви и ее представителей к тем или иным погребальным практикам и институтам. Более того, создавая легальную основу для кремации, декрет о похоронах давал право приверженцам новой практики апеллировать напрямую к го- 
сударству в части формирования похоронной политики. Гражданские инженеры, коммунальщики, общественники, возбуждая вопрос о строительстве крематория в том или ином городе, вступали в прямой контакт с совнаркомами, наркоматами здравоохранения, внутренних дел и коммунального хозяйства, ссылаясь при этом на гигиенические, экономические, эстетические преимущества новой погребальной практики и полностью оставляя в стороне вопросы веры. Следуя букве декретов, не запрещавших исполнение религиозных обрядов жизненного цикла, а оставлявших это на откуп родственникам, активисты пропагандировали новую практику как необходимую, но совершенно добровольную, снимая тем самым проблему неприятия кремации носителями традиционных взглядов.

Отделение Церкви от государства и лишение монополии на погребение не просто позволяет похоронным реформаторам принимать решения в обход ее мнения. Государственная политика форсированной секуляризации принципиально по-новому разворачивает ключевой вопрос погребальной культуры: кто владеет мертвыми телами? С точки зрения Т. Уолтера, ответ на этот вопрос и создает ту конфигурацию похоронных практик, которую мы можем найти в той или иной культуре (Walter 2005, 2012). Традиционно в христианском мире, в том числе и в Российской империи, именно Церковь была тем институтом, который многие столетия обладал полной монополией на мертвые тела. Именно у церкви были власть и авторитет, позволявшие ей диктовать, где и как должен быть похоронен умерший. Советское государство, придерживаясь идей секуляризации и примата светскости, было нацелено на разрушение влияния Церкви: Церковь не должна иметь доходов, не должна владеть землей, недвижимостью и обрядами жизненного цикла, а следовательно, и самими гражданами - живыми или мертвыми. И это значит, что санкция на распоряжение мертвыми телами (также как и живыми людьми, недвижимостью и пр.) переходит от старого принципала (Церкви) к новому, не вполне еще сформировавшемуся и функционирующему (советскому государству). Именно на осуществление этого перехода направлены первые советские декреты, отчуждающие разнообразные права и функции Церкви в пользу государства. Такого рода резкая, директивная, не продуманная в деталях и технике исполнения (хотя, несомненно, и ожидаемая многими членами общества) передача важнейших функций, поддерживающих стабильность в обществе и влияющих на его воспроизводство, не имела прецедентов в мировой истории. Великая французская революция, с которой часто сравнивают ранние советские преобразования, все же не была экспериментом такого же масштаба и такой же продолжительности (Prothero 2001: 9; Trompette 2013: 373-374).

Новый «режим распоряжения телами» дает возможность советским приверженцам кремации увидеть свою миссию в ином свете. В Москве и других городах, поглощенных эпидемиями и похоронным кризисом, доминирующий санитарно-гигиенический дискурс рассматривает кремацию только как практику утилизации мертвого тела (body disposal practice); в результате происходит полное рассоединение индивидуальности человека и его тела. Неопознанные, разлагающиеся тела это просто тела, останки, мусор, который необходимо утилизировать как можно скоpee (Merridale 2002: 132). Поэтому для инженеров и чиновников не имеет значения, каким будет крематорий: временной деревянной постройкой или перестроенным промышленным зданием. Основным вопросом при таком подходе становится логистика доставки тел из мест их наибольшего скопления, отправной же точкой ока- 
зывается скорее похоронный кризис, а не идея реализации кремационного проекта как такового. Полное рассоединение индивидуальности и тела приводит к тому, что человек с его мыслями и чувствами, переживаниями и скорбью полностью исчезает из построений сторонников кремации: мертвое тело может беспокоить живых лишь как источник заразы, но не как объект острого чувствования. Об этом они как будто случайно вспоминают, когда врачи Солдатенковской больницы отказываются размещать кремационную станцию прямо в лечебном учреждении, объясняя это тем, что пациенты должны быть нацелены на выздоровление, чему никак не может способствовать ежедневно наблюдаемый ими дым от утилизации тел своих менее удачливых соседей по палате (ГАМО. Оп. 1. Д. 51. Л. 3). Только после выступления врачей приверженцы санитарного подхода как будто заново открывают для себя человеческую индивидуальность, а также переживания живых, связанные с мертвым телом, и начинают размышлять о том, что нужно как-то учитывать и психологические аспекты кремации. Неудивительно при этом, что в фокусе внимания сторонников санитарного подхода - безродные, неопознанные, административные покойники, а не добровольно выбравшие кремацию как способ погребения еще при жизни.

\section{Строительство «Крематориума-Храма»}

Однако полное рассоединение индивидуальности человека и его тела, произошедшее на пересечении создания нового режима распоряжения мертвыми телами и ситуации массовой гибели от эпидемий, не исчерпывало полностью повестку введения кремации в советской России. Одновременно с инициативами строительства трупосжигательных станций в Москве, попытки создания крематория делаются и в Петрограде. Старая столица находилась в гораздо лучшем санитарном положении, чем новая, а муниципальные структуры города на Неве работали гораздо четче. Возможно, именно это стало причиной того, что первый кремационный проект в Петрограде оказался не только более успешным, но и гораздо более идеологически взвешенным. 26 января 1919 г., т.е. менее чем через два месяца после принятия декрета «О кладбищах и похоронах», Совет комиссаров союза коммун Северной области принимает декрет «Об образовании Постоянной комиссии по постройке Первого государственного крематория и морга в Петрограде» (далее - комиссия) (ЦГА СПб 1. Л. 3, 16об, 17). Понимание целей и путей реализации этого декрета петроградскими инженерами и коммунальщиками серьезно отличается от подхода их московских коллег.

Уже сам факт, что инициатива постройки крематория в Петрограде сразу оформлена в виде декрета и что это происходит на несколько месяцев раньше, чем в Москве, говорит о многом. Более того, комиссия сразу ставит вопрос о практической реализации кремации в принципиально иную рамку, объявляя конкурс на архитектурный проект здания крематория (ЦГА СПб 1. Л. 3). Это, в свою очередь, позиционирует крематорий как значимый градостроительный объект большой архитектуры и важный идеологический проект молодого государства. И даже то, что крематорий предполагается разместить на окраине города, является не признаком его малого или чисто утилитарного значения, а следствием особенностей архитектурного и градостроительного понимания стоящей перед комиссией задачи:

Ввиду отсутствия в центре города больших и свободных площадей, [комиссия] постановила произвести выбор места на окраинах города. Последнее 
решение помимо чисто санитарного своего значения создаст для строителей большой простор в смысле выбора стиля, ибо последний не будет связан стилем близ стоящих зданий, что было бы неминуемо в случае возведения Крематориума в центре города (ЦГА СПб 1. Л. 3., Зоб).

Таким образом, оказывается, что архитектурная целостность проекта невозможна в исторических районах города, наполненных многими смыслами. Более того, в старом мире центральной застройки этот объект стилистически просто не мог существовать.

Конечно, отношение к крематорию, как к важному монументальному объекту, не исключает полностью гигиенического дискурса. Инженеры и санитарные врачи неоднократно обращают внимание комиссии на острую эпидемическую ситуацию и важность новой похоронной практики для ее разрешения, утверждая, что «этот вопрос принял характер вовсе не той спешности, какую... требуют от него условия данного момента» (ЦГА СПб 1. Л. 16).

Казалось бы надвигающаяся гроза должна сдвинуть вопрос о кремации в сторону скорейшего устройства районных трупосожигательных станций, как к мере экстренного характера, в виду грозной опасности. <..>

Если к общей картине полного развала санитарной части населенных центров прибавить наличие непохороненных покойников, то явления принимают кошмарный характер.

Если все старания санитарных властей привести города в порядок и сейчас разбиваются о разные препятствия вроде отсутствия транспорта, рабочих и пр., то что же нас ожидает летом, когда эпидемии начнут косить сотнями и тысячами в сутки (ЦГА СПб 1. Л. 16об).

Известные гражданские инженеры, уже зарекомендовавшие себя специалисты по строительству мусоросжигательных станций, Н.Н. Козлов и Н.Н. Епишкин представляют в комиссию свои проекты кремационных печей, временных трупосжигательных станций и приспособления отдельных производственных строений (сгоревшая тюрьма - литовский замок, одно из зданий Патронного завода на Выборгской стороне) для нужд крематория (ЦГА СПб 1. Л. 16-17, 21), рассматривая все это как средства, «которые могли бы принести большую экономическую и санитарную пользу до постройки предполагаемого грандиозного Крематориума» (ЦГА СПб 1. Л. 21). Однако ни соображения инженеров, ни даже ходатайство заведующего городским Медико-санитарным отделом о необходимости строительства временного крематория (ЦГА СПб 1. Л. 21) не меняют позиции комиссии.

Комиссия не разделила приведенной точки зрения, полагая, что трупозжигательная станция едвали в состоянии привлечь к себе симпатии населения между тем означенный вопрос нельзя игнорировать при постройке первого в городе Крематориума. Последний своим внешним видом той идеи которая найдет в себе воплощение в постройке, должен всячески содействовать [со] зданию в массах необходимого духовного настроения, которое только и способно сделать идею трупозжигания приемлемой для населения.

В виду сего Комиссия полагала предпочтительным постройку Крематориума-Храма (ЦГА СПб 1. Л. 2об). 
Традиционно на протяжении многих столетий едва ли не единственным местом, где могло создаваться «в массах необходимое духовное настроение», была церковь (православный храм). И именно церковь была тем местом, где заканчивался земной путь каждого православного подданного империи. Таким образом, лишая церковь монополии на погребение и владение телами, идеологи кремации стремятся создать новую форму погребения, которая тем не менее будет отвечать старым, привычным духовным потребностям.

Идея строительства «Крематориума-Храма» взамен православного храма, несмотря на свою внешнюю провокативность, только подчеркивает преемственность новой практики и старой погребальной культуры и невозможность (невзирая на огромное желание) разрыва внутренней связи между ними. Даже опираясь на политику форсированной секуляризации, советские сторонники кремации пытаются воспроизводить старые христианские формы, обращаясь к европейский универсалии - использованию пространства храма для похоронно-поминальной обрядности. Как показывает практика, эта универсалия столь сильна, столь прочно закреплена в культуре, что ее невозможно отменить никаким волевым усилием (политическим или идеологическим), она будет воссоздавать сама себя даже в среде атеистически настроенных большевиков.

Однако дискуссия о строительстве крематория не исчерпывалась обсуждением его архитектурных форм, вопрос о месте расположения объекта был не менее важен. В комиссии представитель комздрава доктор С. Каменцер отстаивал точку зрения о необходимости размещения крематория на одном из кладбищ на окраине города, как это принято на западе, указывая на следующие преимущества:

а) Родственное чувство близких к покойнику людей не будет задето при сознании, что покойники тем или иным способом будут преданы земле при обстановке, связанной с представлением о кладбище.

б) Помимо всего желательно место закрытое, т.е. богатое растительностью (деревьями) дабы подвоз большого количества покойников не был так заметен непричетному (непричастному. $-A$.C.) к покойникам населению.

в) Нахождение крематориума на кладбище не вызвало бы необходимости отчуждения каких либо других участков города, занятых нужными постройками или предназначенных для других общественных целей (ЦГА СПб 1. Л. 3).

Доктор С. Каменцер, внося это предложение, несомненно, озабочен фактом разрыва и противопоставления «Крематориума-Храма» (как нового инструмента обращения с мертвыми телами) и кладбища (как старого и более привычного инструмента погребения, находящегося в той или иной степени в сфере церковного влияния). По сути, его предложение - это попытка оспорить новое право на владение мертвыми телами и найти тот язык и те аргументы, которые позволят сделать этот разрыв менее болезненным. Сознание того, что покойники будут «преданы земле при обстановке, связанной с представлением о кладбище»- не важно каким именно способом будет при этом утилизовано тело, - должно успокоить родственные чувства близких, поскольку захоронение на кладбищенской территории, пусть даже и кремационного праха, как будто возвращает статус кво, утвержденный предыдущими столетиями: мертвые тела находятся в освященной, огороженной кладбищенской земле. Сделать 
новую практику более неприметной, спрятать крематорий в зелени деревьев, не отчуждать под него новые городские пространства - все это находится в противоречии с программой строительства «Крематориума-Храма», который самим своим видом должен декларировать не просто новый порядок погребения, а новую символическую монополию на мертвые тела: теперь они принадлежат государству и это должно быть ясно с первого взгляда.

Неудивительно поэтому, что комиссия не принимает доводы доктора С. Каменцера и выбирает в качестве приоритетной площадки для строительства «Крематориума-Храма» площадь на берегу Невы, занятую амбарами, принадлежавшими первоначально Александро-Невской лавре, а позднее Петроградскому компроду. На тот момент амбары были переоборудованы в единственные в городе склады, куда товары доставлялись исключительно водным путем, и играли чрезвычайно важную роль в снабжении Петрограда продовольствием. В связи с этим комиссии было отказано в выделении данной территории.

В качестве альтернативной площадки рассматривался другой участок, также примыкающий вплотную к Александро-Невской лавре, - парк, расположенный на Обводном канале рядом с монастырским кладбищем. Выбор был обусловлен следующими факторами: во-первых, территория давала «возможность проявлению свободного творчества, не связанного стилем окружающих сооружений», во-вторых, она в наибольшей степени отвечала задачам улучшения санитарной ситуации, поскольку располагалась вблизи кладбища на окраине города, в местности с наибольшей смертностью. Таким образом, этот участок удовлетворял как соображениям доктора С. Каменцера, так и основополагающим идеям комиссии (ЦГА СПб 1. Л. 3, Зоб).

М. Шкаровский в своей работе «Строительство Петроградского (Ленинградского) крематория как средства борьбы с религией» предполагает, что выбор места для строительства первого петроградского крематория диктовался в первую очередь желанием нового правительства непременно расположить его в стенах Александро-Невской лавры, чтобы таким образом подчеркнуть антирелигиозное значение нового объекта (Шкаровский 2006). Однако, как видно из протоколов собраний комиссии, оба рассматриваемых участка располагались за пределами монастыря, монастырского кладбища и основных церковных построек и, хотя и находились до революции в управлении лавры, на момент строительства были национализированы и заняты городскими складами. На мой взгляд, периферийное положение территории, дававшее полную свободу в архитектурных экспериментах и позволявшее без затруднений подвозить стройматериалы, играло если и не бо́льшую, то точно не меньшую роль в выборе строительной площадки, чем антирелигиозные соображения.

Несомненно, понимание задачи строительства крематория как возведения грандиозного архитектурного объекта возникает как часть идеи о фундаментальном значении монументальной пропаганды в первые послереволюционные годы и как следствие бурного ритуального творчества тех лет и стремления выразить новые революционные идеалы через памятники, уличные акции, оформление городского пространства и т.д. Сама архитектурная форма, выбранная для «Крематориума-Храма», должна была нести не меньший идейный посыл, чем практика кремации. Для комиссии важна не только реализация проекта как такового, но и его художественная составляющая, которая должна будет расположить людей к новой погребальной практике. Таким образом, с самого начала кремационный проект выходит далеко за 
рамки санитарного, в его основе концепт достойного, красивого погребения, которое должно быть «в полной мере удовлетворяющим чувства эстетики и уважения к умершему» (Кремация 1937).

\section{Практика кремации}

Какой бы важной не была идея строительства «Крематориума-Храма» в Петрограде, она так и осталась неосуществленной. Величественное здание, которое могло бы «[со]здавать в массах необходимое духовное настроение», так и не было спроектировано и построено. Несмотря на всю настойчивость комиссии в получении места рядом с Александро-Невской лаврой, территория не была выделена. Начинавшаяся гражданская война требовала больших ресурсов. Перебои с материалами и рабочей силой заставили Петросовет и комиссию отложить строительство «Крематориума-Храма». По-видимому, немаловажную роль в этом сыграло и отрицательное отношение горожан, в т.ч. верующих, к проекту (Шкаровский 2006). Между тем санитарно-эпидемическая обстановка ухудшалась. Под влиянием обстоятельств комиссия возвращается к предложению инженера Н.Н. Козлова об открытии временных трупосжигательных станций.

Постоянная Комиссия считает долгом отметить, что постройка помянутых станций, кроме того, дала бы возможность проверить на практике работу и пригодность разных конструкций печей, а равно выяснить наиболее полезные условия их постройки и эксплоатации, каковой опыт окажет неоценимую пользу постройке 1-го государственного Крематориума в столице (ЦГА СПб 1. Л. 28).

В результате первый петроградский крематорий был открыт в помещении бывших бань на ул. Камской Васильевского Острова. Символично, что со сменой места строительства меняется и название объекта: вместо возвышенного «крематориума» появляется более привычный «крематорий». Но даже в этом крайне компромиссном помещении глава комиссии Б. Каплун пытается по мере возможности реализовать идею «Крематориума-Храма». Помещение должно было иметь своды (как в храме), а не обычный потолок. Для этой цели при перестройке здания

[в] зале Прощания установлены деревянные столбы, облицованные мрамором и шифером <..> Зал второго этажа перекрыт фальшивым коробовым с распалубками, сводом из вагонки. Для устройства этого зала были удалены чугунные колонны, несущие перекрытие по железным балкам и заменены деревянной подкосной конструкцией, замаскированной означенным сводом (ЦГА СПб 2. Д. 7. Л. 201).

В вестибюле был установлен мраморный камин, «подготовлены две мраморные стильные скамьи», стены облицованы мрамором или подготовлены под роспись маслом, установлен мраморный катафалк на мраморном возвышении (ЦГА СПб 2. Д. 7. Л. 158об). Однако свидетельства о реальной практике кремации говорят о том, насколько далек оказался первый в советской России крематорий от образа храма. Наиболее яркое свидетельство можно найти в дневнике К.И. Чуковского в записи от 3 января 1921 г., фрагменты которой я привожу ниже: 
...здание недоделанное, но претензии видны колоссальные. Нужно оголтелое здание преобразовать в изящное и грациозное. Баня кое-где облицована мрамором, но тем убийственнее торчат кирпичи. Для того чтобы сделать потолки сводчатыми, устроены арки - из... из... дерева, которое затянуто лучиной. Стоит перегореть проводам - и весь крематорий в пламени.

Каплун $<\ldots>$ с аппетитом стал водить нас по этим исковерканным залам, имеющим довольно сифилитический вид. И все кругом вообще сифилитическое: мрачные, каторжные лица с выражением застарелой зубной боли мрачно цепенеют у стен. К досаде пикникующего комиссара, печь оказалась не в порядке: соскочила какая-то гайка. Послали за спецом Виноградовым, но он оказался в кинематографе. В печи отверстие, затянутое слюдой, - там видно беловатое пламя - вернее, пары напускаемого в печь газа. <..>

Долго и канительно возились сифилитики с газом. Наконец молодой строитель печи крикнул: - Накладывай! - похоронщики в белых балахонах схватились за огромные железные щипцы, висящие с потолка на цепи, и, неуклюже ворочая ими и чуть не съездив по физиономиям всех присутствующих, возложили на них вихляющийся гроб и сунули в печь, разобрав предварительно кирпичи у заслонки.

Смеющийся Грачев очутился в огне. Сквозь отверстие было видно, как горит его гроб - медленно (печь совсем холодная), как весело и гостеприимно встретило его пламя. Пустили газу - и дело пошло еще веселее. <...>

Мы по очереди заглядывали в щелочку и с аппетитом говорили друг другу: «раскололся череп», «загорелись легкие», вежливо уступая дамам первое место. Гуляя по окрестным комнатам, я со Спесивцевой незадолго до того нашел в углу... свалку человеческих костей. «Летом мы устроим удобрение!»потирал инженер руки (Чуковский 1991: 153).

Своего рода открытие крематория на Камской улице состоялось 14 декабря 1920 г., когда в торжественной обстановке был сожжен труп красноармейца Малышева. Опытное сжигание, на котором присутствовали помимо Б. Каплуна Н. Гумилев и Ю. Анненский, было признано успешным. Технические испытания печей проводились вплоть до 21 февраля 1921 г., когда по некоторым данным печи вышли из строя. За это время было сожжено 379 умерших (332 мужчины, 22 женщины, 25 детей и подростков). Подавляющее большинство тел было кремировано в административном порядке и только 16 - по желанию родных или согласно завещанию. Такое соотношение могло обуславливаться несколькими факторами. Крематорий к этому времени находился в недостроенном состоянии, поэтому и все сжигания стоит признать пробными, техническими. Этим отчасти объясняется и та странная атмосфера, которую описывает в своем дневнике К.И. Чуковский. По-видимому, эти 16 сожженных согласно завещанию сами были сторонниками кремационного движения. Кроме того, кремация стоила в несколько раз дороже трупоположения, что в ситуации жесточайшего кризиса этих лет, несомненно, играло существенную роль.

Хотя технически первый крематорий был способен сжигать тела умерших, идея грандиозного «Крематориума-Храма» не была реализована в нем ни в малейшей степени. Обращаясь в сентябре 1921 г. в президиум ВСНХ РСФСР с ходатайством о внеочередном отпуске средств на завершение работ по строительству крематория, комиссия отмечает: 
Кремационный метод погребения является чрезвычайно ценным в санитарном отношении в особенности в периоды эпидемий; с этой точки зрения очень важно расширить его применение по всему Государству. Для указанной цели необходима активная его пропаганда, которая будет наиболее реальной, если население будет видеть вполне благоустроенный, исправно функционирующий Крематориум.

Ввиду изложенного Научно-экспертная комиссия полагает, что представляется настоятельно необходимым докончить отделку здания Крематориума как снаружи, так и внутри, придав этой отделке художественные формы, соответствующие назначению помещений, это послужит к удовлетворению эстетического чувства населения и примирительно повлияет с этической стороны; те же соображения имеют место и к кремационной печи (РГАЭ. ОП. 3. Д. 2. Л. 9).

В январе 1922 г., в связи с полным прекращением финансирования и завершением работ по программе-минимум, глава комиссии Б. Каплун обращается в похоронный подотдел петроградского Отдела коммунального хозяйства с письмом, в котором извещает, что постройка кремационной печи закончена, и печь может приступить к работе в любой день, производя до 35 трупосжиганий в сутки, расходуя при этом до 2 кубических саженей дров (т.е. около 2 машин в сутки, что с учетом топливного кризиса 1921-1922 гг. было огромным объемом). Отмечая, что «с точки зрения организационной эксплуатация крематория не входит в круг ведения комиссии по постройке» и что «[в] трупосожигании заинтересовано непосредственно коммунальное хозяйство по похоронному отделу», Б. Каплун спрашивает: «...считает ли целесообразным Отдел Коммунального хозяйства работу крематория в настоящее время», «...согласится ли он взять на себя эксплуатацию крематория» и «...хватит ли у отдела коммунального хозяйства материальных возможностей для эксплуатации крематория». Настоятельные вопросы Б. Каплуна объясняются, по-видимому, тем, что комиссия получила к этому времени «заявление от группы лиц о желании взять эксплуатацию крематория в арендное пользование» (ЦГА СПб 2. Д. 26. Л. 1, 1об). Такого рода предложение было в целом в русле общих подходов к похоронному менеджменту 1922-1923-х гг. и не должно было вызывать особенного удивления в Отделе коммунального хозяйства. Ответ на запрос Б. Каплуна не заставил себя ждать и был более чем жестким. Член коллегии Петрогуботкомхоза, заведующий подотделом хозяйственных предприятий Савин сообщал, что «с хозяйственной точки зрения эксплоатация крематория в настоящее время представляется невыгодной по сравнению с захоронением трупов, и Отдел Коммунального Хозяйства не намерен теперь эксплоатировать его» (ЦГА СПб 2. Д. 26. Л. 2). Не видя никаких экономических перспектив деятельности крематория, Отдел коммунального хозяйства принимает решение о его консервации. В ноябре 1922 г. окна здания были заложены кирпичом, фронтоны фасадов зашиты досками (ЦГА СПБ 2. Д. 26. Л. 37).

Однако, кроме очевидных экономических причин закрытия проекта петроградского крематория, существовал и ряд других, делавших невозможной эксплуатацию возведенного сооружения. Хотя к октябрю 1922 г. степень готовности объекта оценивалась комиссией в 65 \%, президиум Петрогубэкосо, проведя ряд дополнительных ревизий строительства, приходит к выводу, что даже при минимально необходимой достройке крематорий будет в таком виде, что сможет использоваться лишь для «сжигания преимущественно трупов из учреждений Губздравотдела и администра- 
тивных» (ЦГА СПБ 2. Д. 7. Л. 202). Все эти причины четко уловил К.И. Чуковский, рефлексируя над собственным поведением при посещении крематория:

Мы смеёмся, никакого пиетета. Торжественности ни малейшей. Все голо и откровенно.

Ни религия, ни поэзия, ни даже простая учтивость не скрашивает места сожжения.

Революция отняла прежние обряды и декорумы и не дала своих. Все в шапках, курят, говорят о трупах, как о псах. <..>

В самом деле: что за церемонии! У меня все время было чувство, что церемоний вообще никаких не осталось, всё начистоту, откровенно. Кому какое дело, как зовут ту ненужную падаль, которую сейчас сунут в печь. Сгорела бы поскорее - вот и всё. Но падаль, как назло, не горела. Печь была советская, инженеры были советские, покойники были советские - всё в разладе, кое-как, еле-еле. Печь была холодная, комиссар торопился уехать. - Скоро ли? Поскорее, пожалуйста. - Еще 20 минут! - повторял каждый час комиссар. Печь остыла совсем (Чуковский 1991: 153).

Проект, задуманный как величественный «Крематориум-Храм», не смог в итоге стать ни «Храмом», ни «Крематориумом». Конечно, получившееся сооружение, отражавшее все проблемы советской бесхозяйственности, в котором тела тлели часами в холодных печах, никак не справлялось с поставленной задачей «всячески содействовать [со]зданию в массах необходимого духовного настроения». Этот опыт оказался ярким столкновением двух важных, но малосочетаемых трендов - сохранения архетипа храма, создающего необходимое духовное настроение, и деконструирования смерти - рассоединения телесной смерти, утилизации мертвого тела и духовного переживания смерти. Именно в этом смысле «революция отняла старые декорумы», но не смогла создать нового способа удовлетворения базовых потребностей в переживании смерти.

\section{Донской крематорий - храм будущего}

Первым стабильно работающим крематорием стал Донской крематорий в Москве. Открытый в 1927 г. через пять лет после окончательной консервации петроградского проекта он, казалось бы, полностью противоречил идее грандиозного «Крематориума-Храма». Под Донской крематорий решено было перестроить и адаптировать уже имеющееся здание. В качестве такового был выбран храм св. Серафима Саровского и Анны Кашинской на новом кладбище Донского монастыря на юге города близ Окружной дороги. Реконструкция здания означала фактически полную его перестройку и в первую очередь его десакрализацию, деконструкцию образа храма. Выбранный в результате конкурса проект архитектора Д.П. Осипова предполагал изменение конструкции верхней части здания (крыши, колокольни) с тем, чтобы ничто не напоминало о его прежнем храмовом облике. Стоит отметить, что в качестве альтернативного рассматривался проект архитектора К.С. Мельникова, раскритикованный комиссией как раз за схожесть его форм с церковными.

Таким образом, в отличие от программы строительства первого крематория в Петрограде, в Москве в 1927 г. не шло никакой речи о создании «Крематориума-Храма» - планируемый объект вписывался уже не в традиционный, а в новый модерни- 
стско-технологический контекст похоронной культуры. Само место строительства московского крематория имело огромное значение для понимания его роли в советском модернистском проекте. Южные окраины Москвы, прилегающие к окружной железной дороге, к моменту переноса столицы из Петрограда представляли собой малонаселенные и неблагоустроенные рабочие районы с развивающимися промышленными предприятиями. Однако в ви́дении ведущих советских архитекторов юго-запад должен был стать основным вектором расширения столицы, а новые кварталы должны были застраиваться таким образом, чтобы создавать принципиально новую среду для жизни советских рабочих. Именно это отношение к юго-западным окраинам в итоге нашло отражение в генеральном плане Москвы 1935 г.

Одним из первых символов нового района, обновленной Москвы и новой жизни в целом становится Шуховская телебашня, построенная в 1922 г. в нескольких сотнях метров от Донского монастыря. Именно на этой башне («Радиобашне Коминтерна») были размещены передающие антенны сначала первого в СССР радио, а затем и телевидения. Радиовышка высотой 160 м была в то время самым высоким сооружением не только в столице, но и в стране. В 1927-1929 гг. в районе строятся первый в СССР дом-коммуна - дом кооперативного товарищества «1-е Замоскворечье» и Хавско-Шаболовский жилмассив. В этом контексте предстает перед нами крематорий в публицистике 1920-х годов как один из важнейших кирпичиков нового города - нового мира, построенного на научных началах, мира полного торжества рационализма:

Новое побеждает старое.

Вот оно, это новое: величественное, урбанистическое здание крематория.

Вдали вышка радиостанции им. Коминтерна!..

А вот старое: красные стены былого Донского монастыря.

Где еще так разительно различие веков «нынешнего» и «минувших», где еще в мире - вышка радио и крематорий вырисовываются на фоне красных стен XVI века и шатровых колоколен, с которых глядел еще Дмитрий Донской $<\ldots>$

Мы уходим от этого огненного кладбища. Мощным и легким видением встает радиовышка...

Строятся заводы и фабрики. Дышит мощно земля под белым снежным покровом.

Бегут трамваи. Идут экскурсии в Музей Донского монастыря. Ревут фабричные трубы... (Маллори 1927: 16).

Донской крематорий прекрасно вписался в раннесоветские утопии «городов будущего» с их строгим функционализмом и отсутствием «лишнего» (Хан-Магомедов 2001), а его строительство в центре нового Шаболовского рабочего поселка говорит нам о том, как важен этот тип погребения для человека будущего - не меньше, чем обобществленный быт или радио. Рационализм кремации как идеального научного способа погребения вполне соответствовал рационализму нового городского планирования. Высокая технологичность и гигиеничность позволяли кремации преодолеть множество проблем, дополняя ее преимущества как «культурного, разумного, экономного и красивого способа погребения» (Бартель 1925: 4). В представлении современников введение кремации вело к более рациональному использованию территорий: оно должно было сохранить земли для нужд сельского хозяйства и полно- 
стью освободить города от новых захоронений и кладбищ. «Вместо кладбища надо построить крематорий, а на месте кладбища разбить парк. Парк с театром, кино и культурными развлечениями. Кладбища из места пьянки, разврата и разбоя должны превратиться в места подлинного отдыха рабочего» (Зудин и др. 1929: 70-71). Таким образом, строительство крематория оказывается в одном ряду с новой урбанизационной программой городского планирования. Основанные на примате «научной организации быта трудящихся» оба эти проекта призваны создать новую, принципиально иную среду для советских граждан, среду, базирующуюся на чистоте, рациональности и здоровье. Становясь частью нового ландшафта утопии, крематорий вписывается в новую повестку: новая погребальная практика - это часть нового мира, основанного на технологиях, мира, в котором актуальные образы смерти фактически вытеснены (Соколова 2018).

$$
* * *
$$

Таким образом, революция и политика форсированной секуляризации, проводимая молодым советским государством, создают уникальную ситуацию, в которой российские приверженцы кремации могут продвигать новую похоронную практику, полностью отказавшись от ориентации на любые религиозные учения, институты или практики. Однако даже в этой ситуации принципиальной свободы кремация устойчиво вписывается в привычный контекст традиционных религиозных форм.

После неудачного опыта строительства грандиозного «Крематориума-Храма» в Петрограде, проект Донского крематория в Москве носит нарочито антирелигиозный характер. Церковь св. Серафима Саровского и Анны Кашинской полностью перестраивается, так что в архитектурном облике нового объекта едва ли можно найти сходство с церковным зданием. Донской крематорий встраивается в новый модернистский Хавско-Шаболовский жилмассив как один из символов нового мира наряду с домами-коммунами и Шуховской башней. Таким образом, формируется семантическая инверсия; десакрализованный крематорий, потеряв всякое сходство с храмами прошлой эпохи, оказывается точкой сборки представлений о новом мире, о месте человека в нем, о жизни и смерти человека.

\section{Источники и материалы}

ГАМО - Государственный архив Московской области. Фонд 4557 (Московское коммунальное хозяйство).

Кремация 1973 - Кремация // Большая советская энциклопедия. Т. 34. М.: Советская энциклопедия; ОГИЗ, 1937. С. 713.

Маллори Д. Огненные похороны // Огонек. 1927. № 50. С. 16.

ЦГА СПб 1 - Центральный государственный архив Санкт Петербурга. Фонд р-2815 (Комиссариат здравоохранения Союза Коммун Северной области. Петроград. 1918-1919). Оп. 1. Д. 320.

ЦГА СПб 2 - Центральный государственный архив Санкт Петербурга. Фонд 3181 (Санаторно-курортный трест ленинградского городского отдела здравоохранения. Ленинград. 1935-1939). Оп. 1.

РГАЭ - Центральный Государственный архив экономики. Фонд 2266 (Управление городского и сельского строительства Главного комитета Государственных сооружений ВCHХ РСФСР /Архитстрой/). 


\section{Научная литература}

Бартель Г. Кремация. М.: Изд-во МКХ, 1925.

Белякова Е.В. Церковный суд и проблемы церковной жизни. М.: Культурный центр «Духовная литература», 2004.

Блэк М. Смерть в Берлине. От Веймарской республики до разделенной Германии. М.: НЛО, 2015. Зудин И.И., Мальковский К., Шалашов П. Мелочи жизни. Ленинград, 1929.

Соколова А.Д. Новый мир и старая смерть: судьба кладбищ в советских городах 1920-1930-х годов // Неприкосновенный запас. 2018. № 1 (117). С. 74-94.

Хан-Магомедов С. Архитектура советского авангарда: В 2-х т. М.: Стройиздат, 1996-2001.

Чуковский К.И. Дневники (1901-1929). М.: Советский писатель, 1991.

Шкаровский М. Строительство Петроградского (Ленинградского) крематория как средство борьбы с религией // Клио. 2006. № 3. С. 158-159.

Bremborg A. Professionalization without Dead Bodies: The Case of Swedish Funeral Directors // Mortality. 2006. No. 11 (3). P. 270-285.

Goody J., Poppi C. Flowers and Bones: Approaches to the Dead in Anglo and Italian Cemeteries // Comparative Studies in Society and History. 1994. No. 36. P. 146-175.

Jupp P.C. From Dust to Ashes: Cremation and the British Way of Death. Basingstoke: Palgrave Macmillan, 2006.

Laderman G. Rest in Peace: A Cultural History of Death and the Funeral Home in Twentieth Century America. N.Y.: Oxford University Press, 2003.

Merridale C. Night of Stone: Death and Memory in Twentieth-Century Russia. N.Y.: Viking Penguin Books, 2002.

Prothero S.R. Purified by Fire: A History of Cremation in America. Los Angeles: University of California Press, 2001.

Sloane D. The Last Great Necessity: Cemeteries in American History. Baltimore: Johns Hopkins University Press, 1991.

Suzuki H. The Price of Death, the Funeral Industry in Contemporary Japan. Stanford: Stanford University Press, 2000.

Trompette P. Political Exchanges in the French Funeral Market // Management \& Organizational History. 2011. No. 6 (1). P. 13-35.

Trompette P. The Politics of Value in French Funeral Arrangements // Journal of Cultural Economy. 2013. No. 6 (4). P. 373-374.

Walter T. Three Ways to Arrange a Funeral: Mortuary Variation in the Modern West // Mortality. 2005. No. 10 (3). P. 173-192.

Walter T. Why Different Countries Manage Death Differently: A Comparative Analysis of Modern Urban Societies // The British Journal of Sociology. 2012. No. 63 (1). P. 123-145.

\section{References}

Bartel, G. 1925. Krematsiia [Cremation]. Moscow: MKH.

Beliakova, E. 2004. Tserkovnyi sud i problemy ttserkovnoi zhizni [Church Court and the Problems of Church Life]. Moscow: Kul'turnyi tsentr «Dukhovnaia literatura».

Black, M. 2015. Smert'v Berline. Ot Veimarskoi respubliki do razdelennoii Germanii [Death in Berlin: From Weimar to Divided Germany]. Moscow: NLO.

Bremborg, A. 2006. Professionalization without Dead Bodies: The Case of Swedish Funeral Directors. Mortality 11 (3): 270-285.

Chukovskii, K.I. 1991. Dnevniki (1901-1929) [Diaries (1901-1929)]. Moscow: Sovetskii pisatel'. Goody, J., and C. Poppi. 1994. Flowers and Bones: Approaches to the Dead in Anglo and Italian Cemeteries. Comparative Studies in Society and History 36: 146-175.

Jupp, P.C. 2006. From Dust to Ashes: Cremation and the British Way of Death. Basingstoke: Palgrave Macmillan. 
Khan-Magomedov, S. 1996-2001. Arhitektura sovetskogo avangarda [Architecture of the Soviet Avantgarde], 2 vols. Moscow: Stroiizdat.

Laderman, G. 2003. Rest in Peace: A Cultural History of Death and the Funeral Home in Twentieth Century America. New York: Oxford University Press.

Merridale, C. 2002. Night of Stone: Death and Memory in Twentieth-Century Russia. New York: Viking Penguin Books.

Prothero, S.R. 2001. Purified by Fire: A History of Cremation in America. Los Angeles: University of California Press.

Shkarovskii, M. 2006. Stroitel'stvo Petrogradskogo (Leningradskogo) krematoriia kak sredstvo bor'by s religiei [Construction of the Petrograd (Leningrad) Crematorium as a Means of Struggling Against Religion]. Klio 3: 158-159.

Sloane, D. 1991. The Last Great Necessity: Cemeteries in American History. Baltimore: Johns Hopkins University Press.

Sokolova, A.D. 2018. Novyi mir i staraia smert': sud'ba kladbishh v sovetskih gorodah 1920-1930h godov [New World and Old Death: The Fate of Cemeteries in Soviet Cities of the 19201930s]. Neprikosnovennyj zapas 1 (117): 74-94.

Suzuki, H. 2000. The Price of Death, the Funeral Industry in Contemporary Japan. Stanford: Stanford University Press.

Trompette, P. 2011. Political Exchanges in the French Funeral Market. Management \& Organizational History 6 (1): 13-35.

Trompette, P. 2013. The Politics of Value in French Funeral Arrangements. Journal of Cultural Economy 6 (4): 373-374.

Walter, T. 2005. Three Ways to Arrange a Funeral: Mortuary Variation in the Modern West. Mortality 10 (3): 173-192.

Walter, T. 2012. Why Different Countries Manage Death Differently: A Comparative Analysis of Modern Urban Societies. The British Journal of Sociology 63 (1): 123-145.

Zudin, I.I., K. Malkovskii, and P. Shalashov. 1929. Melochi zhizni [Little Things of Life]. Leningrad.

Sokolova, Anna D.

\section{Crematorium-Church, or Cremation in the Soviet Burial Ritual in 1920-s}

The article discusses the history of the introduction of cremation in the USSR in the context of funeral culture secularization processes. In the Western European context, as in Russia before the revolution, the legalization and spread of cremation was significantly limited by the enormous influence of the Church, which traditionally opposed this new type of burial. In the USSR, after the Decree on the separation of the church from the state, a unique situation developed in which all decisions regarding the disposal of dead bodies were made directly by the civil authorities, based mainly on considerations of sanitation and hygiene in large cities. However, as it turned out when building the first crematorium in Petrograd, the main focus when choosing a project and place of construction was "creating the necessary spiritual mood among the masses," and the building itself was called the CrematoriumChurch. Thus, despite the radical change in the "control over dead bodies" (Walter) and the transition of the monopoly on burial from the Church to a deliberately secular state, the ideologists of cremation in the Soviet Russia continued to tend to a quasi-religious design for the new funeral practice. However, by the second half of the 1920s, when the Donskoy crematorium was being built in Moscow, the attitude to cremation as a technology turned out to be much more important, and the crematorium no longer fit into the quasi-religious, but into the technological framework.

Key words. Cremation, USSR, atheism, body disposal practices 